\title{
Pelatihan Tata Cara dan Etika Melamar Kerja dalam Bahasa Inggris bagi Siswa SMAN 1 Batulayar Kabupaten Lombok Barat
}

\author{
Tri Setianingsih, Siti Syafi'atul Qomariyah, Bq. Zuhrotun Nafisah, Terasne \\ Universitas Pendidikan Mandalika \\ *Corresponding Author. Email: trisetianingsih@undikma.ac.id
}

\begin{abstract}
The purpose of community service activities is to increase insight into ethics and procedures for applying for jobs in English which will be needed for students at SMAN 1 Batulayar, to enter the world of work after graduating from school. During the pre-test before the implementation of the service activities, it was found that almost $90 \%$ of the 20 grade 3 students at SMAN 1 Batulayar did not know the ethics and procedures for applying for jobs in English. So it can be said that this activity is very useful for students. The method used in this service is the diffusion of knowledge and the practice of implementing ethics and procedures for applying for jobs in English. The result of this service activity is that the third grade students participating in this activity become more enthusiastic and more confident in learning conversation and vocabulary related to job interviews in English. Moreover, our team also provides a pocket book in the form of summaries of several interviews and how to write a job application letter in English which they can learn whenever they want. This can be seen from the post test results after this service activity was carried out, namely an increase from 20 students who did not understand everything, almost 90\%, namely 18 students understood ethics and procedures for applying for jobs in English.
\end{abstract}

Abstrak: Tujuan dari kegiatan pengabdian masyarakat adalah untuk meningkatkan wawasan dalam beretika dan tata cara melamar kerja dalam bahasa Inggris yang sangat dibutuhkan oleh siswa SMAN 1 Batulayar, untuk terjun dalam dunia kerja setelah lulus dari bangku sekolah. Saat pre-tes sebelum pelaksanaan kegiatan pengbdian diketahui bahwa hampir 90\% dari 20 siswa kelas 3 di SMAN 1 Batulayar belum mengetahui etika dan tatacara melamar kerja dalam Bahasa Inggris. Sehingga dapat dikatakan kegiatan ini sangat bermanfaat bagi siswa. Metode yang digunakan dalam pengabdian ini yakni difusi ilmu pengetahuan dan praktek pelaksanaan etika dan tatacara melamar kerja dalam Bahasa Inggris. Hasil dari kegiatan pengabdian ini yakni para siswa kelas tiga peserta kegitan ini menjadi lebih bersemangat dan lebih percaya diri dalam belajar conversation dan kosakata yang berhubungan dengan interview kerja dalam Bahasa Inggris. Selain itu tim pengabdi juga memberikan buku saku berupa rangkuman beberapa interview dan cara menulis surat lamaran kerja dalam Bahasa Inggris yang bisa dipelajari kapan saja. Hal ini dapat diketahui dari hasil post test setelah dilakukan kegiatan pengabdian ini yakni peningkatan dari 20 siswa yang tidak mengerti semuanya hampir 90\% yakni 18 siswa memahami etika dan tata cara melamar kerja dalam Bahasa Inggris.

How to Cite: Setianingsih, T., Qomariyah, S., Nafisah, B., \& Terasne, T. (2021). Pelatihan Tata Cara dan Etika Melamar Kerja Dalam Bahasa Inggris Bagi Siswa SMAN 1 Batulayar Kabupaten Lombok Barat. Jurnal Pengabdian UNDIKMA, 2(2), 293-300. doi:https://doi.org/10.33394/jpu.v2i2.4329

\section{Article History:}

Received: 27-08-2021

Reviewed: 29-09-2021

Accepted: 22-10-2021

Published: 13-11-2021

\section{Key Words:}

Procedures

Applying.

\section{Sejarah Artikel:}

Diterima: 27-08-2021

Direview: 29-09-2021

Disetujui: 22-10-2021

Diterbitkan: 13-11-2021

\section{Kata Kunci:}

Pelatihan, Etika, Tata

Cara Melamar Kerja
Training, Ethics, 


\section{Pendahuluan}

Kecemasan bagi setiap kelulusan adalah sulitnya dalam mencari pekerjaan. Tak terkeacuali bagi para lulusan SMA. Seperti yang kita ketahui bahwa jumlah para lulusan, baik SMA dan Perguruan tinggi, tidak sebanding dengan banyaknya jumlah lowongan kerja yang tersedia di negara kita ini. Penelitian yang dilakukan oleh M. Rosyid Hidayat (2014) tentang tingginya tingkat pengangguran sarjana di Indonesia, dimana hasil dari penelitian tersebut adalah: tingginya jumlah pengangguran sarjana disebabkan karena memiliki keterampilan yang rendah dan belum siap mental untuk memasuki dunia kerja. selain karena sumber daya manusia yang kurang berkualitas, kurangnya jumlah lapangan pekerjaan padat karya yang mampu menyerap tenaga kerja, sehingga mendorong tingginya tingkat pengangguran di Indonesia.

Tenaga kerja yang dimaksud merupakan penduduk yang berada dalam usia kerja. Menurut UU No. 13 tahun 2003 Bab I pasal 1 ayat 2 disebutkan bahwa tenaga kerja adalah setiap orang yang mampu melakukan pekerjaan guna menghasilkan barang atau jasa baik untuk memenuhi kebutuhan sendiri maupun untuk masyarakat Sehingga setelah lulus sekolah Menengah Atas setiap anak/siswa berhak dan boleh untuk mencari kerja. Di Indonesia, dari sisi tenaga kerja, globalisasi memberikan kesempatan yang setara bagi Warga Negara Asing maupun Warga Negara Indonesia untuk mencari pekerjaan di Indonesia. Sehingga tentunya dibutuhkan banyak sumber daya manusia (SDM) yang berkualitas untuk menghindari SDM Indonesia menjadi pengangguran di negeri sendiri. Kekhawatiran ini cukup beralasan karena pada tataran realita dalam kurun waktu 2005 sampai dengan 2009 terjadi peningkatan jumlah tenaga kerja asing (TKA) yang bekerja di Indonesia.

Pulau Lombok merupakan salah satu daerah destinasi wisata di Indonesia. Pariwisata telah menjadi salah satu industry dengan pertumbuhan tercepat di dunia dalam kurun waktu dua puluh tahun terakhir. UNWTO mencatat rekor bahwa jumlah wisatawan Internasional pada tahun 2012 mencapai 1 milyar wisatawan dengan pendapatan ekspor Internasional sebesar 1,3 triliun US\$. Pada tahun berikutnya yaitu 2013 terjadi peningkatan menjadi 1,08 milyar. jumlah wisatawan Internasional diperkirakan pada tahun 2020 akan meningkat menjadi 1,4 milyar, dan menjadi 1,8 milyar pada tahun 2030. Dari data tersebut, diperkirakan 57\% wisatawan akan mengunjungi destinasi wisata di Negara berkembang yang perekonomiannya sedang tumbuh, seperti halnya Indonesia. Banyak Negara yang menjadikan pariwisata sebagai sektor andalan dalam membangun kekuatan perekonomiannya termasuk Indonesia, hal ini disebabkan sector pariwisata mempunyai banyak keuntungan, dilihat dari data pada tahun 2013 yang menunjukan bahwa sector pariwisata Internasional menyumbangkan 9\% PDB internasional, 1 dari 11 lowongan pekerjaan di sector pariwisata, 6\% ekspor dunia, dan 6\% ekspor Negara-Negara miskin.

Potensi pariwisata yang dimiliki oleh pulau Lombok ini merupakan salah satu usaha pemerintah dalam rangka mengoptimalisasi sumber sumber pendapatan daerah yang bertujuan meningkatkan kesejahteraan masyarakat, dengan menempatkan sektor pariwisata sebagai sektor andalan kedua setelah sektor pertanian dalam arti luas. Sebagai salah satu daerah tujuan wisata Pulau Lombok mempunyai potensi besar untuk dikembangkan. Potensi wisata yang dimiliki Pulau Lombok adalah wisata budaya dan alamnya yang sangat mendukung pengembangan pembangunan pariwisata di Lombok. Keadaan alamnya yang masih asli merupakan daya tarik tersendiri bagi wisatawan yang datang berkunjung di pulau Lombok. Sehingga nantinya dapat menambah pendapatan untuk daerah secara khusus dan merupakan suatu keuntungnan bagi Indonesia khususnya Pulau Lombok. Nusa Tenggara Barat selaku pelaksana urusan rumah tangga daerah dan pembangunan pariwisata, dalam hal 
ini yang bertanggungjawab terhadap pengembangan dan pembangunan pariwisata. Mempunyai Visi “Terwujudnya Nusa Tenggara Barat sebagai Daerah Tujuan Wisata Berdaya Saing Internasional. Destinasi pariwisata berdaya saing internasional dimaksudkan sebagai kemampuan relative suatu destinasi pariwisata dibandingkan dengan destinasi pariwisata lain di tingkat internasional untuk memenuhi kebutuhan, menjadi pilihan dan menarik calon wisatawan untuk datang berwisata, yang ditentukan oleh faktor : atraksi atau daya sektor, dan faktor umum (sarana, prasarana, serta fasilitas pendukung).

Salah satu faktor yang mendukung berkembangnya suatu daerah pariwisata adalah factor SDM (Sumber Daya Manusia). Dimana SDM ini merupakan pelaku dari pelaksana jasa pariwisata baik yang bekerja sebagai jasa pemandu wisata, perhotelan, jasa transpotrtasi ataupun jasa-jasa lainnya. Bagi orangtua yang mampu sangatlah mudah untuk memberikan pendidkan lanjutan yang memadai (Perguruan Tinggi ataupun kursus) selepas anaknya menempuh Pendidikan di Sekolah Menengah Atas (SMA). Tetapi bagi orang tua yang tidak mampu akan menuntut atau mengharapkan anaknya untuk segera mendapatkan pekerjaan selepas lulus SMA untuk memenuhi kebutuhan hidupnya sendiri dan membantu menopang perekonomian orang tuanya.

Berdasarkan observasi sebelum pelaksanaan kegiatan ini di SMAN 1 Batulayar, bahwa kemampuan Bahasa Inggris adik-adik kelas 3 ini masih jauh dari harapan para guru Bahasa Inggris. Terutama dalam segi etika melamar kerja dan vocabulary atau kosa kata dalam melamar kerja seperti membuat surat lamaran kerja dalam Bahasa Inggris dan interview. Adapun kegiatan pengabdian ini bertujuan untuk memberikan pelatihan untuk menngkatkan wawasan dalam beretika dan tata cara melamar kerja dalam bahasa Inggris yang akan sangat dibutuhkan bagi para siswa di SMAN 1 Batulayar khususnya, untuk terjun dalam dunia kerja setelah lulus dari bangku sekolah.

\section{Metode Pengabdian}

Metode dalam melaksanakan pengabdian masyarakat ini menggunakan pelatihan yang partisipatif dimana tim ikut melibatkan pihak siswa dan pihak sekolah lainnya seperti kepala sekolah, guru dan staff untuk berpartisipasi dalam kegiatanini demi kelancaran kegiatan (Rizka \& Tamba, 2018; Huda \& et. al. 2019; Setianingsih et. al. 2020). Kegiatan Pelatihan Tata Cara dan Etika Melamar Kerja Dalam Bahasa Inggris Bagi Siswa SMAN 1 Batulayar ini menggunakan tiga langkah kegiatan ini yakni gabungan antara metode Teori, Praktik Langsung dan Sharing. Ketiga langkah kegiatan tersebut digunakan sebagai acuan agar telaksananya kegiatan berjalan secara efektif dan efisien agar tujuan dari kegiatan ini dapat berjalan secara maksimal.Kegiatan pengabdian in berjalan selama 6 bulan sesuai dengan jadwal dan dengan melibatkan mahasiswa Bahasa Inggris semester 5 sebanyak 5 orang.

\section{Hasil Pengabdian dan Pembahasan}

Kegiatan pengabdian pada masyarakat ini ditujukan pada siswa kelas tiga pada SMAN 1 Batulayar yang terdiri dari dua kelas IPA dan satu kelas IPS, dimana masingmasing kelas terdiri 20 orang siswa. Pemilihan kelas dilakukan oleh wakil kepala sekolah bagian kesiswaan sesuai dengan pertimbangan kemampuan dasar siswa dalam menguasai Bahasa Inggris. Para siswa mendapatkan sharing ilmu melalui presentasi dari tim pengabdian lewat Slide Proyektor disamping mendapatkan pocket e-book.

1) Tahap Requirement (Persiapan)

Tahap ini dimulai dengan melakukan survei terhadap mitra sehingga dapat ditemukan permasalahan apa saja yang ada di antara para siswa tentang dunia kerja, terutama dalam 
Bahasa Inggris. Beberapa kegiatan yang dilakukan dalam tahap ini antara lain: Survei lokasi mitra dan Pembentukan tim dan tugasnya.

2) Tahap Design

Pada tahap ini terdapat pembagian tugas tim sebagai mana tabel berikut:

Tabel 1. Struktur Pembagian kerja Tim

\begin{tabular}{|c|c|c|c|c|}
\hline No & Waktu & Jam & Kegiatan & Tim \\
\hline 1. & 15-03-2021-16-04-2021 & $08.00-10.00$ & $\begin{array}{l}\text {-Survey ke lokasi mitra } \\
\text { untuk mencari tahu } \\
\text { permasalahan apa yang } \\
\text { ada di lokasi mitra dan } \\
\text { peralatan apa saja yang } \\
\text { dibutuhkan selama } \\
\text { kegiatan. } \\
\text {-Penentuan kebutuhan } \\
\text { media (Perangkat Keras } \\
\text { dan Lunak) } \\
\text { Media yang diperlukan } \\
\text { yakni mix atau speaker, } \\
\text { Lcd proyektor, dan } \\
\text { whiteboard, perangkat } \\
\text { lunak yakni pre-test, } \\
\text { post test, e-book etika } \\
\text { dan tata cara melamar } \\
\text { kerja. }\end{array}$ & $\begin{array}{l}\text { Tri } \\
\text { Setianingsih, } \\
\text { S.S., M.Pd }\end{array}$ \\
\hline 2. & $17-04-2021-18-05-2021$ & $08.00-10.00$ & $\begin{array}{l}\text { Pembuatan materi } \\
\text { Pelatihan }\end{array}$ & $\begin{array}{l}\text { Siti Syafi,atul } \\
\text { Qomariyah, } \\
\text { M.Pd. }\end{array}$ \\
\hline 3. & $19-05-2021-20-06-2021$ & $08.00-10.00$ & $\begin{array}{l}\text { Persiapan pembuatan } \\
\text { pretest- post test dan e- } \\
\text { book }\end{array}$ & $\begin{array}{l}\text { Bq. Zuhrotun } \\
\text { Nafisah, MA }\end{array}$ \\
\hline 4. & $21-07-2021-21-08-2021$ & $08.00-10.00$ & $\begin{array}{l}\text { Persiapan peralatan di } \\
\text { lokasi mitra }\end{array}$ & $\begin{array}{l}\text { Terasne, M.Pd. } \\
\text { B.I. }\end{array}$ \\
\hline
\end{tabular}

3) Tahap Implementing

Pada tahap ini kegiatan akan dilaksanakan di SMAN 1 Batulayar pada tanggal 22 September 2021 dan dibuka langsung oleh Bapak Kepala Sekolah SMAN 1 Batulayar.dan diikuti oleh 20 orang siswa kelas 3 tahun ajaran 2020/2021. Partisipasi mitra dalam proses pelaksanaan PKM ini adalah menyediakan tempat dan memobilisasi anggota agar hadir dalam kegiatan pengabdian masyarakat ini. Hasil kegiatan yang ingin dicapai yakni meningkatnya kemampuan para siswa dalam melamar pekerjaan baik dari segi etika maupun melamar kerja linterview dan membuat surat lamaran kerja menggunakan Bahasa Inggris.

Pada kegiatan ini sebelum pelaksanaan kegiatan diadakan pre-test secara tertulis untuk mengetahui kemampuan siswa dalam etika ataupun vocabulary/kosakata dalam melamar kerja. Dari pre-tes tersebut diketahui bahwa hampeir 90\% dari 20 siswa tersebut kurang memahami etika, interview ataupun cara membuat surat lamaran dalam Bahasa Inggris. 


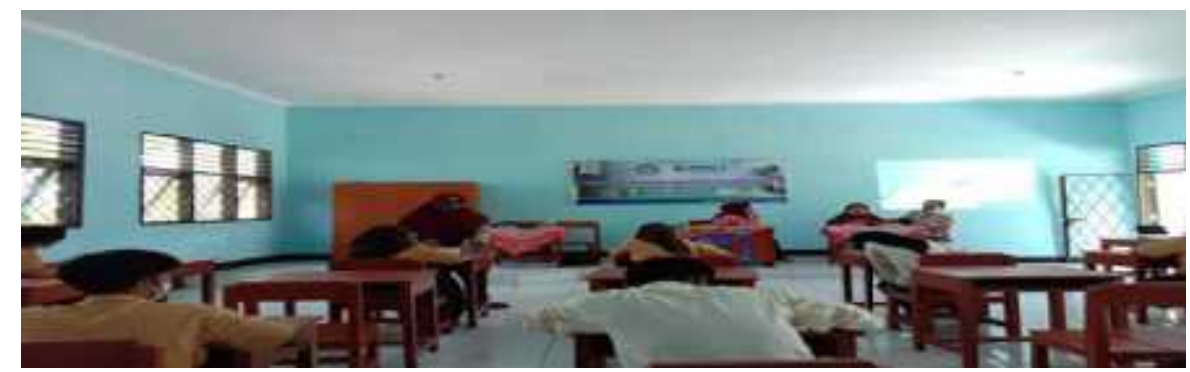

Gambar 1. Pre-test Implementasi Pengabdian

Pengabdian Kepada Masyarakat (PKM) ini bertujuan untuk memberikan pelatihan tata cara dan etika melamar kerja dalam bahasa Inggris bagi siswa SMAN 1 Batulayar. Kegiatan ini telah dilaksankan selama 6 bulan dimulai pada tanggal 15 Maret 2021 sampai dengan tanggal 22 September 2021. Tim PKm terdiri dari 1 ketua tim dan 3 aanggota tim, dengan dibantu lima orang mahasiswa. Sedangkan peserta peserta kegiatan ini semua siswa kelas 3 bejumlah 20 yang terdiri dari 12.laki orang siswa dan 8 perempuan orang siswa. Metode yang digunakan dalam kegiatan pelatihan ini yaitu gabungan antara metode Teori, Praktik Langsung dan Sharing. Teori diberikan pada awal kegiatan guna memaparkan gambaran umum terkait tahapan pelaksaan kegaitan pelatihan dan tata cara dan etika melamar kerja dalam Bahasa Inggris dan kegiatan dilanjutkan memberikan pemahaman tentang beberapa istilah atau kosa kata tentang surat lamaran kerja. Pada tahap selanjutnya yaitu tahapan kedua peserta praktik menulis sebuah surat lamaran kerja dan praktik langsung bagaumana tata cara dan etika disaat melamar suatu pekerjaan yang memperhatikan etika kesopanan dan pada saat interview. Sharing dipergunakan oleh peserta guna menanyakan materi yang masih dirasa belum dipahami atau dirasa masih sangat kurang. Dan diakhir pelaksanaan kegiatan yaitu tahap ketiga yang dimana setiap peserta berkesempatan untuk menampilkan surat lamaran hasil dari kegiatan pelatihan praktik menulis surat lamaran kerja dan interview kepada satu persatu keteman-teman mereka didepan kelas. Kegiatan tersebut dapat dilihat pada gambar berikut :

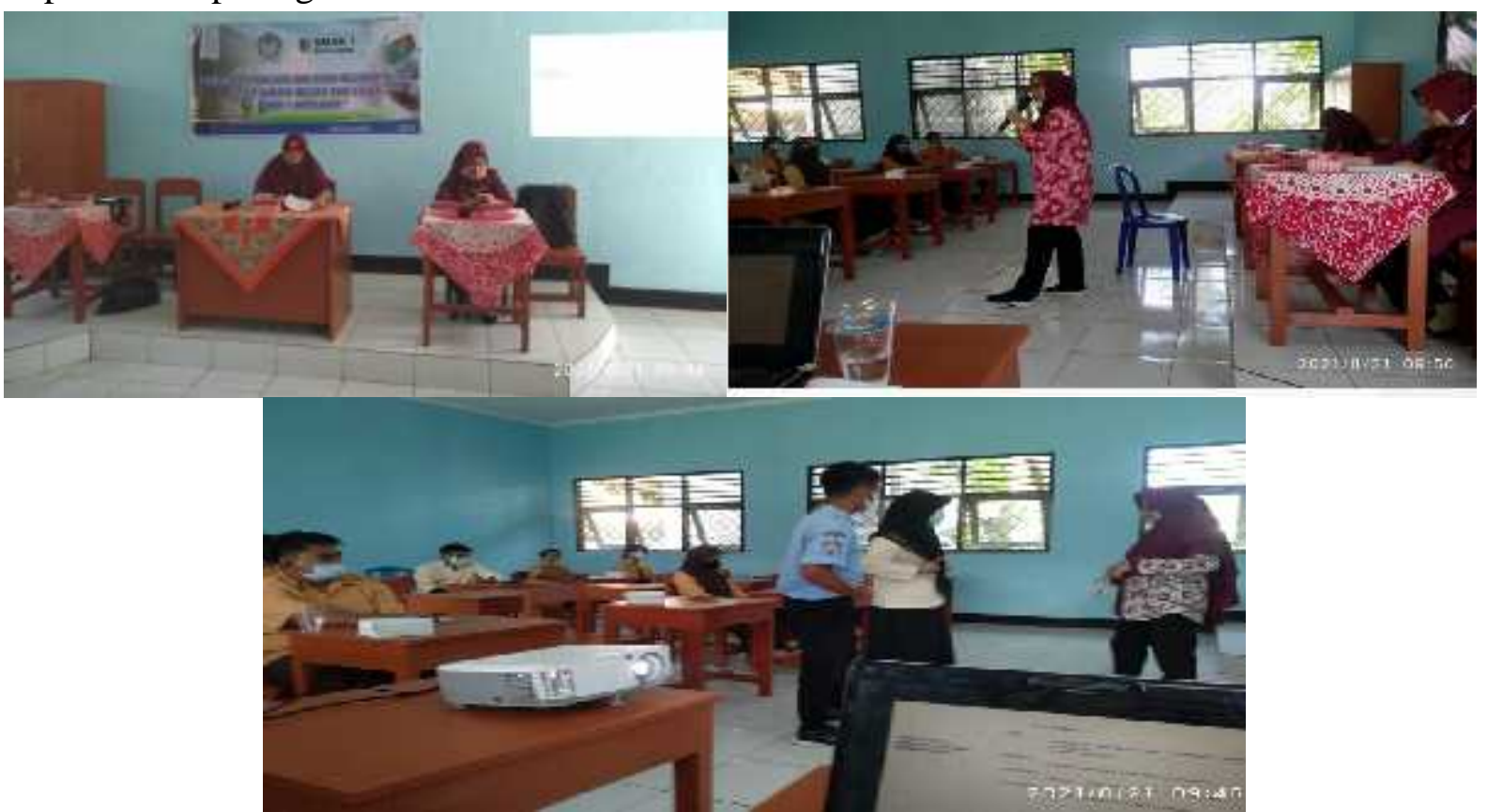

Gambar 2. Proses Pelatihan 


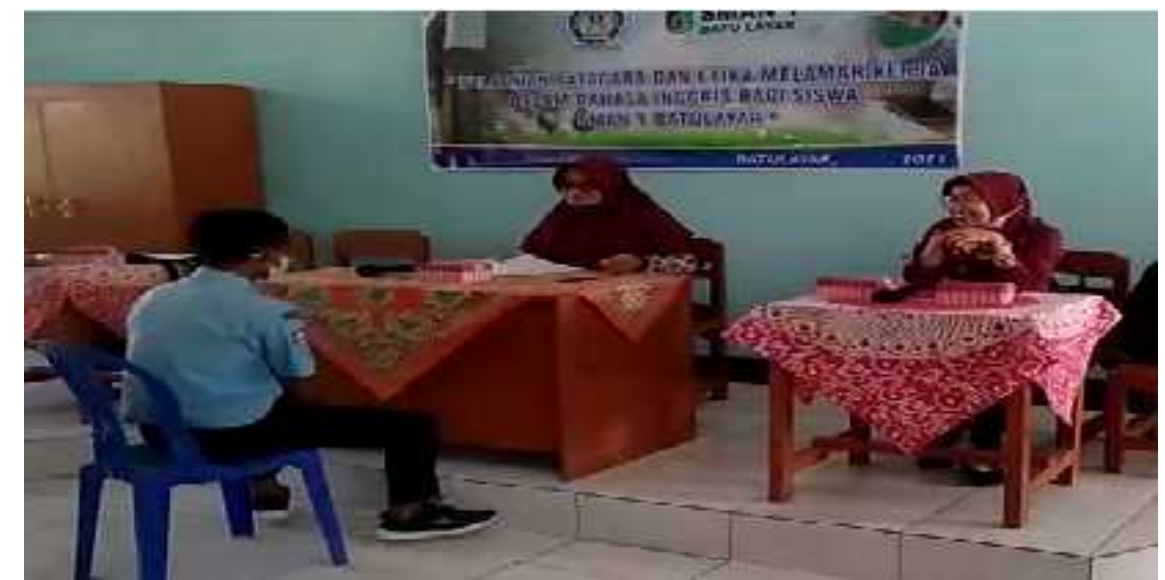

\section{Gambar 4. Salah Seorang Peserta Praktik Langsung Etika Interview}

Pemberian materi disusun berdasarkan hasil dari analisis kebutuhan yang dilihat dari hasil pre test terhadap siswa dimana hampir 90\% dari siswa yakni 18 orang siswa mengalami kesulitan dalam mengerjakan soal mengenai vocabulary melamar kerja, etika dan cara menulis surat dalam Bahasa Inggris di dalam pre-test. Modul Panduan yang diberikan pada saat penyampaian materi yakni sebagai berikut:

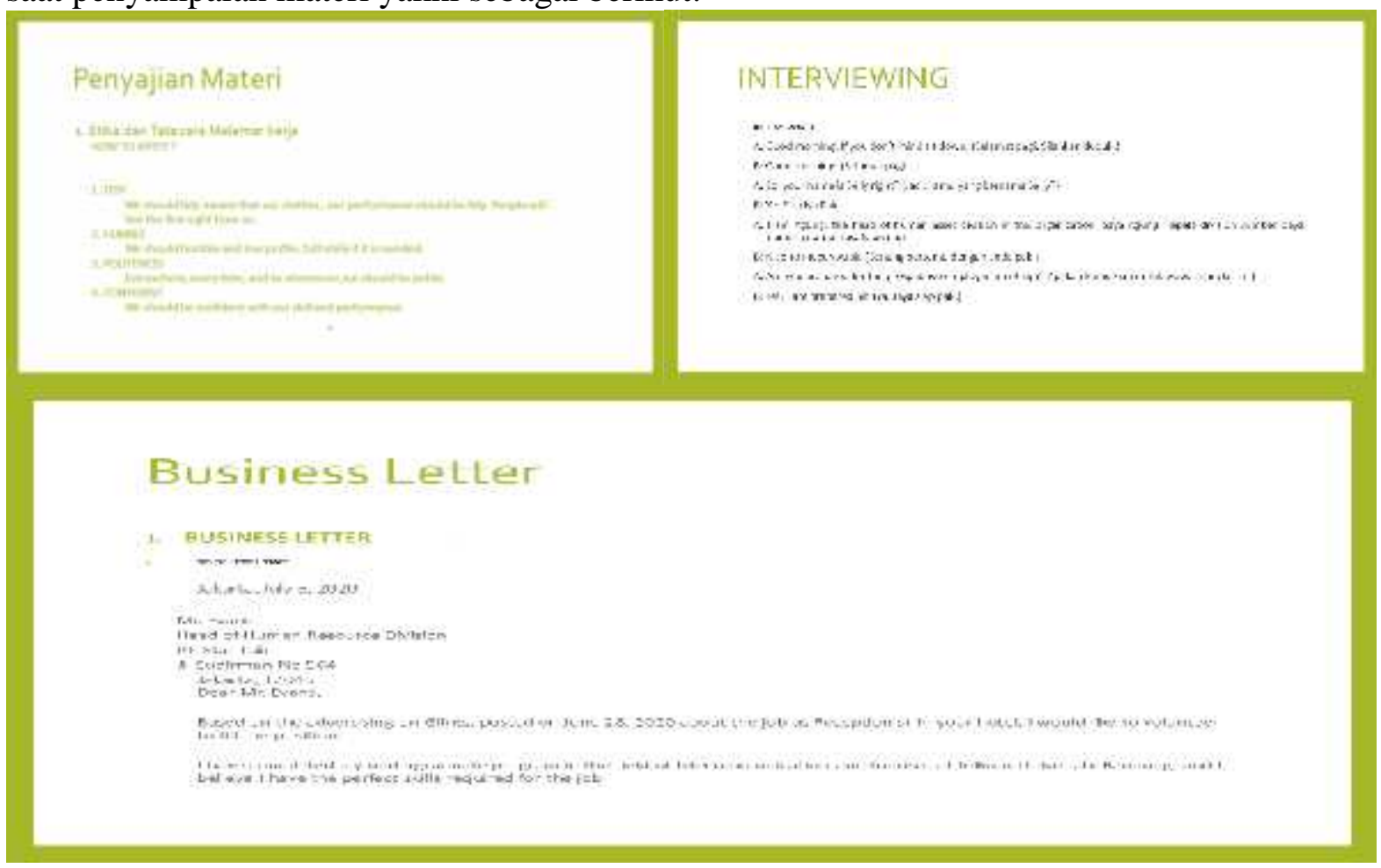

\section{Evaluasi Kegiatan}

\section{Gambar 5. Modul Materi Peelatihan}

Setelah penyampaian semua materi pengabdian selesai , tim PKM berupaya untuk melakukan evaluasi terhadap hasil implementasi dari pelaksanaan kegiatan yang telah diselenggarakan. Evaluasi ini bertujuan untuk mengetahui tingkat keefektifan dari pelaksanaan kegiatan yang telah dilaksanakan. Evaluasi kegitan terdiri dari dua yakni evaluasi proses dan produk (hasil) (Stufflebeam, 2003). Evaluasi proses dalam kegiatan ini terkait evaluasi tingkat partisipasi, 
respon peserta, dan proses penyampaian materi pelatihan. Sedangkan evaluasi produk terkait dengan kemampuan peserta pelatihan dalam menguasai materi dan praktik sesuai prosedur yang tepat.

\section{Evaluasi Proses}

Respon para siswa terhadap kegiatan ini sangt baik. Pihak sekolah baik kepala sekolah, wakasek dan para guru memandang sangat perlu diadakan kegiatan yang serupa secara berkesinambungan. Berdasrkan angket tanggapan terhadap kegiatan pelatihan bisa dilihat dari grafik berikut:

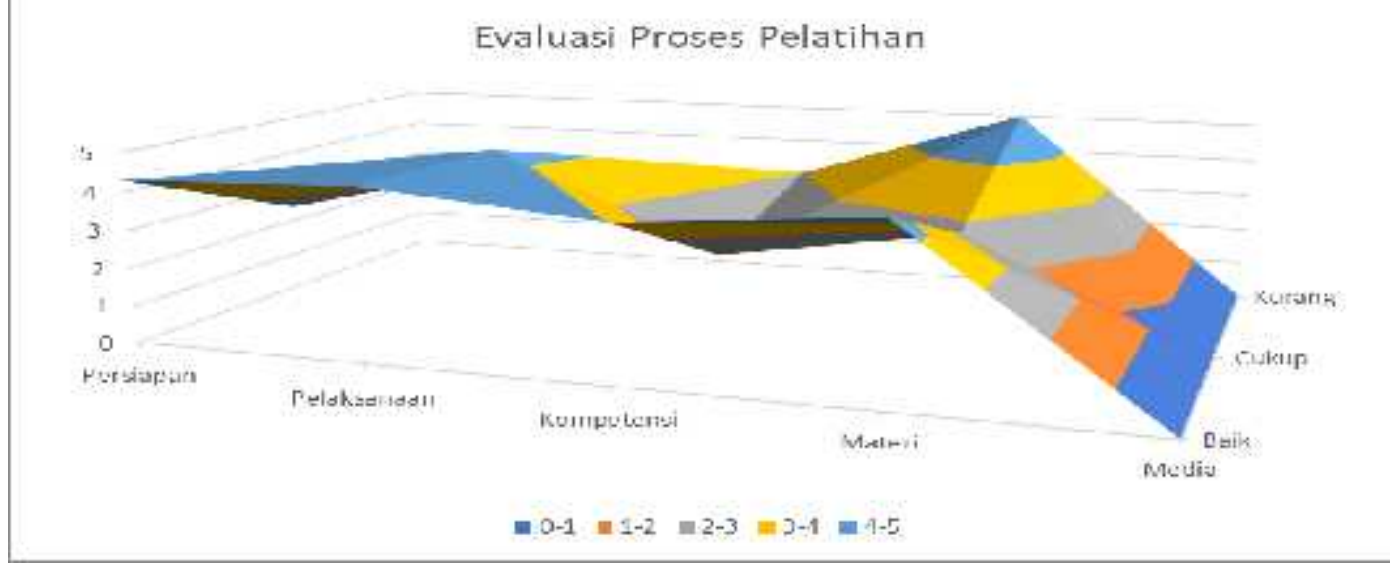

Grafik 1. Respon Peserta Pelatihan

Berdasarkan pada grafik di atas, dapat diartikan bahwa respon siswa terhadap pelatihan ini masuk kategori baik hal ini terlihat dari data grafik yang menunjukan bahwa: 1. Persiapan pelatihanpeserta menjawab dengan baik $80 \%$ dan $20 \%$ cukup; 2. Pelaksanaan peserta menjawab $75 \%$ baik 25\% cukup, 3. Aspek kompetensi Pemateri 90\% baik, $10 \%$ cukup, 4. Materi pelatihan, peserta menjawab $80 \%$ baik, $20 \%$ cukup.

\section{Evaluasi Hasil}

Pada aspek evaluasi hasil pelatihan didapatkan bahwa siswa memahami materi dan dapat melakukan praktik dengan baik. Dalam hal ini tim PKM melakukan pengamatan (observasi) secara cermat dan memberikan penugasan secara mandiri langsung kepada peserta pelatihan untuk mengetahui penguasaan materi dari praktik yang dilakukan. Berikut visualisasi grafik dari kemampuan penguasaan materi dan praktik dari siswa peserta pelatihan.

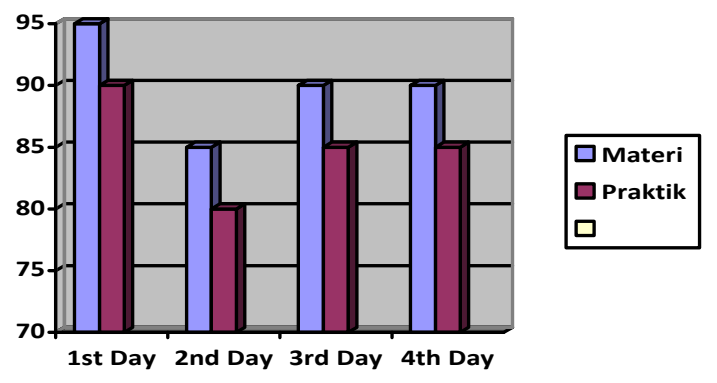

\section{Grafik 2. Kemampuan Peserta Pelatihan}

Dari grafik di atas dapat dikatan bahwa materi etika melamar kerja pada hari pertama 95\% materi diserap dengan baik dan $85 \%$ dapat dilaksanakan dengan baik. Pada hari kedua materi interview $85 \%$ bisa dihapalkan dengan baik, dan $80 \%$ bisa dipraktikan. Pada hari ketiga materi menulis surat lamaran kerja dalam Bahasa Inggris $90 \%$ bisa diserap dengan baik, dan 85\% bisa dipraktikan secara langsung. Pada hari keempat pembuatan Curriculum Vitae $90 \%$ 
juga dapat diserap dengan baik dan $85 \%$ bisa dipraktikan oleh para siswa. Dari keseluruhan kegiatan dapat dikatakan kegiatan pelatihan ini berjalan dengan sukses dan telah mencapai indikator keberhasilan yang telah ditentukan. Indikator keberhasilan dari kegiatan ini yakni: (1) Peserta pelatihan aktif berpartisipasi selama kegiatan berlangsung. Hal ini dapat dilihat dari tingkat kehadiran, aktif berdiskusi dengan pemateri, (2) Peserta pelatihan bisa memahmi materi yang disampaikan yang dibuktikan dengan hasil praktik yang dikategorikan baik.

\section{Kesimpulan}

Hasil dari kegiatan pengabdian ini yakni para siswa kelas tiga peserta kegitan ini menjadi lebih bersemangat dan lebih percaya diri dalam belajar conversation dan kosakata yang berhubungan dengan interview kerja dalam Bahasa Inggris. Selain itu tim pengabdi juga memberikan buku saku berupa rangkuman beberapa interview dan cara menulis surat lamaran kerja dalam Bahasa Inggris yang bisa mereka pelajari kapan saja mereka mau. Hal ini dapat diketahui dari hasil post test kegiatan pengabdian ini yakni peningkatan dari 20 siswa yang tidak mengerti semuanya hampir $90 \%$ yakni 18 siswa memahami etika dan tata cara melamar kerja dalam Bahasa Inggris.

\section{Saran}

Berdasarkan hasil pengabdian yang sudah diperoleh maka disarankan kepada kepala sekolah agar memberikan kesempatan kepada beberapa mitra untuk memberikan kegiatan-kegiatan positif kepada siswa sehingga siswa dapat memperoleh pengetahuan tambahan disamping ilmu yang diperoleh di sekolah. Diharapkan siswa juga dapat memanfaatkan kesempatan yang diberikan oleh pihak sekolah untuk mengikuti pelatihan-pelatihan dari mitra sehingga semakin memperluas ilmu dan wawasannya.

\section{Daftar Pustaka}

Biro Pusat Statistik. (2008). Keadaan Angkatan Kerja dan Tenaga Kerja Indonesia. Berbagai Edisi. BPS

Frendo, Evan. (2005). How to Teach Business English. England: Pearson Education Limited.

Risfianty, D., \& Indrawati, I. (2020). Pemberdayaan Kesehatan Masyarakat Melalui Pengadaan Fasilitas Cuci Tangan pada Masa Pandemi Covid-19 di Masjid dan Mushala Dusun Montong Are Tengah. Jurnal Pengabdian UNDIKMA, 1(2), 94-99. doi:https://doi.org/10.33394/jpu.v1i2.2724

Rizka, M. A., \& Tamba, W. (2019). Pelatihan Evaluasi Program Pendidikan Nonformal Bagi Pengelola Pusat Kegiatan Belajar Masyarakat (PKBM) di Kecamatan Gunungsari Kabupaten Lombok Barat. Paradharma (Jurnal Aplikasi IPTEK), 2(1). DOI: http://dx.doi.org/10.36002/jpd.v2i1.561

Pitartono. (2012). Analisis Tingkat Pengangguran di Jawa Tengah Tahun 1997- 2010. Skripsi S1, Program Sarjana Fakultas Ekonomika dan Bisnis Universitas Diponegoro

Setianingsih, T., Nafisah, B., Rizka, M., Ariani, S., Permadi Utama, I., Qomariyah, S., \& Imansyah, I. (2021). Pelatihan Teknik Pengajaran Vocabulary Berbasis Media Realia bagi Guru TK Bakti Sesela Kabupaten Lombok Barat. Jurnal Pengabdian UNDIKMA, 2(1), 64-72. doi:https://doi.org/10.33394/jpu.v2i1.3470 